\title{
Characterisation of messenger RNA extracted post-mortem from the brains of schizophrenic, depressed and control subjects
}

\author{
C W PERRETT, R M MARCHBANKS, S A WHATLEY \\ From the Department of Biochemistry, Institute of Psychiatry, London, UK
}

SUMMARY Messenger RNA, obtained from post-mortem brain of 10 schizophrenics, five depressed patients and 10 control subjects, was characterised with respect to a number of parameters. It was found that post-mortem delay was not the major factor in determining RNA yield, size (as determined by cDNA synthesis) and biological activity. Biological activity, as determined by in vitro translation in a reticulocyte-lysate system, could be observed using messenger RNA from periods of 0 to 84 hours post-mortem. Two-dimensional gel analysis of the newly-synthesised radiolabelled products obtained from this material revealed several hundred individual species but no consistent degradation of any particular species with post-mortem delay. It is suggested, therefore, that premortem changes are as important as post-mortem changes in determining RNA yield, size and biological activity. Although no consistent difference could be found between patients and controls using any of these parameters, this study confirms that, by isolating messenger RNA from postmortem human brain, valuable information can be gained on gene expression in psychiatric disorders.

There is considerable evidence from classical family, twin and adoption studies for a genetic predisposition to many types of mental disorder, including schizophrenia and affective disorder. ${ }^{12}$ The involvement of specific genetic elements, and therefore transcriptional mechanisms, in the aetiology of affective disorder has recently been confirmed using molecular genetic techniques, with the reported linkage of affective disorder to the insulin/Ha-ras-1 locus on chromosome 11 in a large Amish pedigree. ${ }^{3}$ Despite this finding, the existence of genetic heterogeneity ${ }^{45}$ and uncertainty about the true values of penetrance for the predisposing genes confound the ability of DNA linkage methodology to define the genetic lesions further. It is therefore important to identify transcribed genes which can be envisaged to be associated with those disorders in order to supplement genetic data. One such approach is to compare brain poly(A)containing messenger RNA populations from normal

Address for reprint requests: Dr C W Perrett, Biochemistry Department, Institute of Psychiatry, De Crespigny Park, Denmark Hill, London SE5 8AF, UK.

Received 28 July 1987. Accepted 26 October 1987 and psychiatrically ill patients. With this in mind, we have studied the effects of post-mortem delay on the biological activity and size of poly(A)-containing messenger RNA isolated from schizophrenic, depressed and control brain tissue. Some of the results shown here have already been presented in a preliminary communication. ${ }^{6}$

\section{Methods}

\section{Brain samples}

Brain tissue (10 schizophrenics, five depressed patients and 10 control subjects) was obtained from Dr RH Perry (Newcastle-upon-Tyne General Hospital) and Dr G Reynolds (MRC Neurochemical Pharmacology Unit, Cambridge). Material from both the frontal cortex and caudate nucleus was used. Subjects had died from a variety of causes and post-mortem delay (the time between death and tissue dissection/freezing) varied from 3 to 84 hours. In addition, control tissue (no post-mortem delay) was obtained during a temporal lobe biopsy performed by Mr CE Polkey (Neurosurgical Unit, Maudsley Hospital).

\section{$R N A$ extraction}

Total cellular RNA was extracted from frozen brains essentially as described previously, ${ }^{7}$ using guanidinium thiocyanate and a caesium chloride centrifugation step. 
Poly(A)-containing messenger RNA was obtained from total cellular RNA by using oligo (dT)-cellulose chromatography. ${ }^{8}$ Both total cellular RNA and poly(A)-containing messenger RNA were estimated by A260 measurements. ${ }^{8}$

\section{Protein synthesis and analysis}

Poly(A)-containing messenger RNA $\left(20 \mu \mathrm{g} \mathrm{ml}^{-1}\right)$ was used to direct the synthesis in vitro of proteins in the reticulocytelysate system, using $\left[{ }^{35} \mathrm{~S}\right]$ methionine as radiolabelled precursor, as described previously. ${ }^{7}$ Translation products were analysed using high-resolution two-dimensional gel electrophoresis as described by O'Farrell, ${ }^{9}$ for isoelectric focusing (ISODALT system), and O'Farrell et al, ${ }^{10}$ for nonequilibrium $\mathrm{pH}$ gradient electrophoresis (BASODALT system). Minor modifications were employed in sample solubilisation and $\mathrm{pH}$ gradient generation. ${ }^{7}$

Spot intensities on fluorograms were measured by the densitometric scanning technique of Quitschke and Schechter, ${ }^{11}$ where a value proportional to the volume integral is determined. Intensities were normalised by a comparison with two standard spots (see figs 4 and 5) whose intensity did not vary significantly from controls (as measured by Student $t$ test values; data not shown).

\section{cDNA synthesis and analysis}

cDNA was synthesised by a modification of the procedure described by Arrand. ${ }^{12}$ The incubation mixture $(10 \mu \mathrm{l}$ total volume) contained: $75 \mathrm{mM} \mathrm{KCl}, 3 \mathrm{mM} \mathrm{MgCl}_{2}, 50 \mathrm{mM}$ Tris- $\mathrm{HCl}$ (pH 7.5), $20 \mathrm{mM}$ dithiothreitol, $2.23 \times 10^{-3} \mathrm{~A} 260$ units oligo $(\mathrm{dT})_{12-18}, 12 \mathrm{U}$ placental RNAsin, $100 \mathrm{nM}$ each of dATP, dCTP, dGTP, dTTP, $\left[\alpha-{ }^{32} \mathrm{P}\right] \mathrm{dCTP}(0 \cdot 1 \mu \mathrm{Ci} ; 420$ Ci $\left.\mathrm{mmol}^{-1}\right), 50 \mu \mathrm{gml}^{-1}$ actinomycin $\mathrm{D}, 200 \mathrm{U}$ murine moloney leukaemia virus reverse transcriptase and $50 \mathrm{ng}$ poly(A)-containing messenger RNA. After incubation $\left(37^{\circ} \mathrm{C}, 1 \mathrm{~h}\right)$ the cDNA was ethanol-precipitated and washed three times in $75 \% \mathrm{v} / \mathrm{v}$ ethanol: $25 \% \mathrm{v} / \mathrm{v} 0 \cdot 1 \mathrm{M}$ sodium ace- tate. The cDNA was analysed for size in. a denaturing agarose gel $(1 \% \mathrm{w} / \mathrm{v}$ agarose in $30 \mathrm{mM} \mathrm{NaOH}, 50 \mathrm{mM}$ $\mathrm{NaCl}, 1$ mMEDTA), using alkaline electrophoresis buffer (30 mM NaOH ImMEDTA).

\section{Results}

\section{$R N A$ recovery}

Recovery of both total cellular RNA and poly(A)containing messenger RNA was variable among different brain samples but there were no significant differences between the groups analysed, as measured by Student $t$ test values (tables 1 and 2). There was no marked decrease in total cellular RNA with postmortem delay (fig 1) and, in addition, age at time of death did not affect the RNA yield (results not shown). Similarly, there was no significant change in the poly(A)-containing messenger RNA (expressed either as a percentage of total RNA or in terms of $\mu \mathrm{g}$ $\mathrm{g}^{-1}$ brain) either with post-mortem delay or with age over the range studied (results not shown).

\section{Messenger $R N A$ size}

Poly(A)-containing messenger RNA size was estimated by reverse transcription into cDNA followed by cDNA sizing (fig 2). Although this underestimatesi messenger RNA size owing to premature termination by reverse transcriptase, relative size distributions of samples can be observed. cDNA sizes showed continuous distributions in the range 200-1400 nucleotide residues. There was no significant change in size with post-mortem delay over the time periodo considered.

Table 1 Comparison of total cellular RNA of brain samples

\begin{tabular}{lllll}
\hline Group & $\begin{array}{l}\text { Number of } \\
\text { samples }\end{array}$ & $\begin{array}{l}\text { Total cellular RNA } \\
(\mu g / g(S D))\end{array}$ & $\begin{array}{l}\text { Age } \\
(\text { years }(S D))\end{array}$ \\
\hline Controls* & 6 & $167(58)$ & $73(6 \cdot 9)$ \\
Schizophrenics* & 8 & $184(74)$ & $72(6 \cdot 8)$ & $36 \cdot 5(27 \cdot 7)$ \\
Depressives* & 5 & $207(89)$ & $76(4 \cdot 5)$ & $29 \cdot 6(26 \cdot 1)$ \\
Totalt & 30 & $174(60)$ & & \\
\hline
\end{tabular}

* Comparison of cortex values only.

tIncluding cortex and caudate values plus fresh biopsy material.

Table 2 Comparison of poly $(A)$-containing messenger RNA of brain samples

\begin{tabular}{|c|c|c|c|c|}
\hline Group & $\begin{array}{l}\text { Number of } \\
\text { samples }\end{array}$ & $\begin{array}{l}\text { Poly }(A)- \\
\text { containing } m R N A \\
(\% \text { of total } \\
\text { cellular } R N A(S D)) \ddagger\end{array}$ & Age (years (SD)) & $\begin{array}{l}\text { Post-mortem delay } \\
\text { (hours }(S D))\end{array}$ \\
\hline $\begin{array}{l}\text { Controls* } \\
\text { Schizophrenics* } \\
\text { Depressives* } \\
\text { Total } \dagger\end{array}$ & $\begin{array}{r}5 \\
5 \\
5 \\
16\end{array}$ & $\begin{array}{l}3.93(1.63) \\
2.75(1.72) \\
2.79(1.76) \\
3.19(1.62)\end{array}$ & $\begin{array}{l}73(7 \cdot 5) \\
70(7 \cdot 4) \\
76(4 \cdot 5)\end{array}$ & $\begin{array}{l}43(25.4) \\
58.5(17.4) \\
29.6(10 \cdot 1)\end{array}$ \\
\hline
\end{tabular}

*Comparison of cortex values only.

†Including fresh biopsy material.

†A similar analysis yielded no significant differences when expressed in terms of $\mu \mathrm{g}$ mRNA/g brain tissue. 


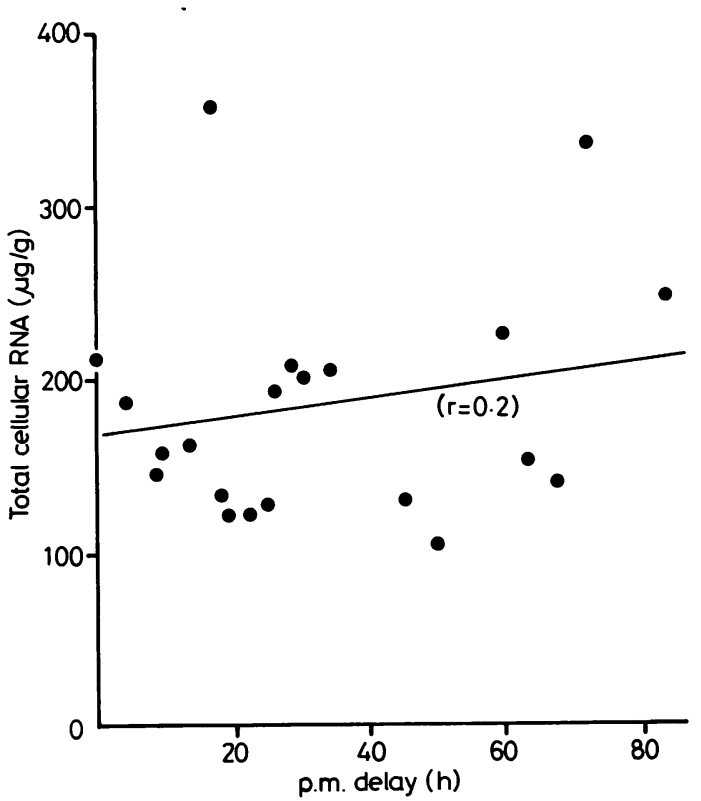

Fig 1 Change in total RNA yield with post-mortem delay in tissue sampling. RNA was isolated and extracted as described in the Methods section. The number in brackets denotes the correlation coefficient value.

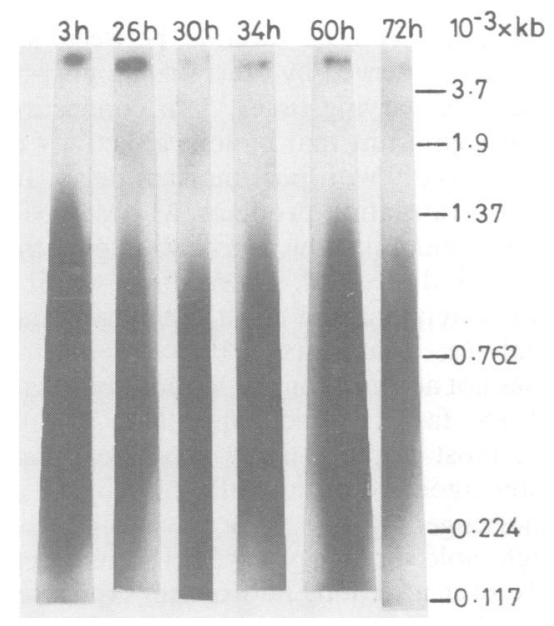

Fig 2 cDNA size estimation. $c D N A$ was synthesised from poly $(A)$-containing messenger $R N A$ and analysed as described in the Methods section. Key: numbers above lanes represent post-mortem delay times; right-hand scale represents the migration of $\mathrm{Mr}$ markers run on the same gel.
Biological activity of messenger RNA

All samples analysed showed biological activity in the in vitro translation system, although there was considerable variation between samples (table 3 ). Student $t$ test results indicated that there were no significant differences between groups (table 3 ) and, perhaps surprisingly, there was no marked reduction in biological activity with post-mortem delay (fig 3 ).

Translation products were analysed using both equilibrium (fig 4) and non-equilibrium (fig 5) twodimensional gel electrophoresis. Analysis of translation product fluorograms revealed a number of proteins which could be consistently identified and over 200 individual radiolabelled species could be detected. No significant amounts of high molecular weight species (Mr greater than 90000) were present in any of the samples analysed. However, there was no consistent shift to lower molecular weight species with increased post-mortem delay, nor any consistent loss of specific individual species (results not shown). It was apparent, therefore, that molecular weight distribution and intensity of specific species was not a simple function of post-mortem factors.

Comparisons of translation product patterns between normal, schizophrenic and depressed patients revealed some differences in relative intensities of specific proteins on some gels (figs 4 and 5). These differences are quantified in table 4. However, comparisons of translation product fluorograms from all samples indicated that there were no consistent differences between either normal and schizophrenic or normal and depressed groups.

\section{Discussion}

RNA recovery

In this study, the yield of both total cellular RNA and of poly(A)-containing messenger RNA from different samples was variable, although the results were consistent with previously published values. ${ }^{73-16}$ Such variation for total RNA is probably not due to impurity of the sample; since RNA obtained by the method used here is relatively free from both $\mathrm{DNA}^{14}$ and protein (different samples had similar A260:A280 ratios; results not shown). Contamination of the sample cannot be discounted for messenger RNA, however, since messenger RNA isolated from an oligo(dT) column contains relatively high levels of ribosomal RNA, ${ }^{714}$ although these levels are still small compared with the total variability observed here. It may be that factors such as tissue dissection, handling and storage play an important part in determining the quantity of RNA recovered. Inclusion of traces of white matter in the sample would affect relative yield, since RNA levels in white matter are only half those in grey matter. ${ }^{17}$ 
Table 3 Comparison of messenger RNA biological activity of brain samples

\begin{tabular}{|c|c|c|c|c|}
\hline Group & $\begin{array}{l}\text { Number of } \\
\text { samples }\end{array}$ & $\begin{array}{l}\text { Biological } \\
\text { activity } \ddagger\end{array}$ & Age (years (SD)) & $\begin{array}{l}\text { Post-mortem delay } \\
\text { (hours (SD)) }\end{array}$ \\
\hline $\begin{array}{l}\text { Controls* } \\
\text { Schizophrenics* } \\
\text { Depressives* } \\
\text { Total } †\end{array}$ & $\begin{array}{r}5 \\
5 \\
5 \\
18\end{array}$ & $\begin{array}{l}3.94(2.42) \\
4.18(2.64) \\
3.32(1 \cdot 10) \\
3.98(2.21)\end{array}$ & $\begin{array}{l}73(7 \cdot 5) \\
70(7 \cdot 4) \\
76(4 \cdot 5)\end{array}$ & $\begin{array}{l}43(25 \cdot 4) \\
58 \cdot 5(17 \cdot 4) \\
29.6(10 \cdot 1)\end{array}$ \\
\hline
\end{tabular}

* Comparison of cortex values only.

†Including cortex and caudate values plus fresh biopsy material.

$\ddagger$ As measured by trichloracetic acid precipitation of synthesised proteins (7); values quoted are -fold stimulation over the blank value and (SD).

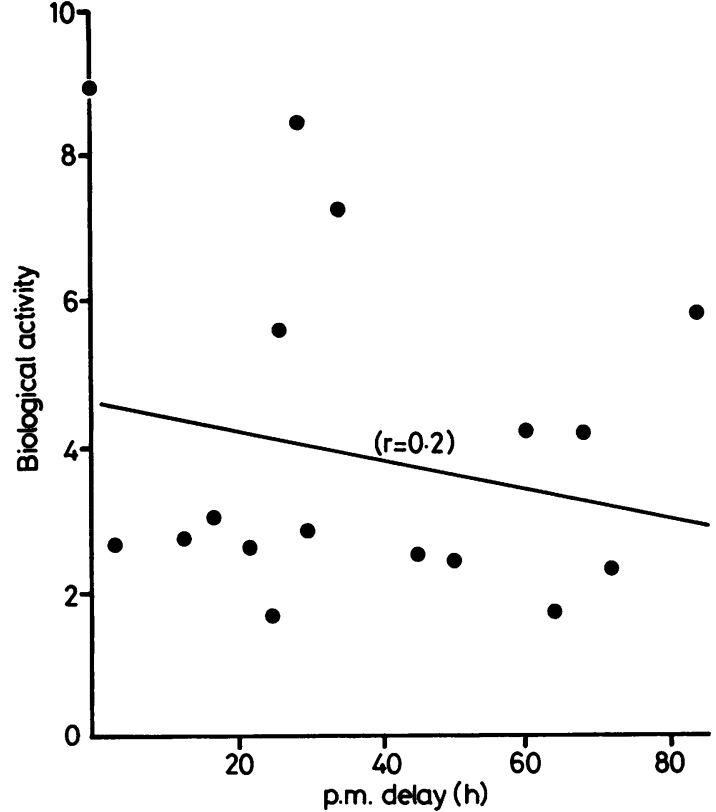

Fig 3 Change in biological activity of messenger RNA with post-mortem delay in tissue sampling. Biological activity was measured by trichloroacetic acid precipitation of synthesised proteins. ${ }^{7}$ Values quoted are -fold stimulation over the blank. The number in brackets denotes the correlation coefficient value.

RNA breakdown, both pre- and post-mortem, thus remains the most obvious determinant of yield of both total RNA and poly(A)-containing messenger RNA. However, there was no correlation observed between low RNA yield and either size of messenger RNA (as judged by reverse transcription) or size of translation products (see below).

\section{Effects of post-mortem delay}

From the results obtained here, and in agreement with others, ${ }^{13-15}$ it appears that post-mortem delay in tissue sampling per se does not significantly affect RNA recovery. Moreover, and surprisingly, post- mortem delay did not appear significantly to affect messenger RNA size, as judged by cDNA analysis. Rather, it is possible that pre-mortem changes may play a more important role than those post-mortem. In support of this proposal, Perry et al ${ }^{18}$ have shown that, when death follows a prolonged period of severe illness, significant differences can be observed in brain tissue $\mathrm{pH}$, as well as some brain amino acid and enzyme levels, compared with those values in patients where death either occurred suddenly or after a period of normal health. Variability in the recovery of $O$ total cellular RNA in this study may therefore be $z \vec{\omega}$ reflection of individual variations in agonal state.

Biological activity

High-resolution two-dimensional gel electrophoresif has been used in a number of studies examining changes in in vitro translation products using messeeg ger RNA isolated from both normal and pathologica human brain. ${ }^{71419-22}$ As with RNA yield, recover $\vec{\theta}$ of biological activity (determined by trichloroacetic $\infty$ acid precipitation) was variable between samples. This has been observed by others using post-mortem brain tissue of varying times. ${ }^{14}$ In connection with this it was significant that biological activity did not decrease markedly with post-mortem delay. In addition, size of translation products, as observed on the fluorograms, did not show degradation over the postmortem period studied. Therefore, whilst RNA degradation remains the most significant factor in such analyses, it appears that post-mortem delay alone does not account for this variability. It is probable that the factors which appear to affect RNA recovery, most notably tissue dissection, handling, storage and agonal state, also affect biological activity of the messenger RNA.

No high molecular weight species were observed in this study, even after long fluorogram exposure times. However, this did not appear to be due to postmortem breakdown of messenger RNA, since messenger RNA derived from freshly frozen biopsy mate- No rial produced translation products of similar size distribution. Differences in translation product sizes observed here, when compared with earlier results, ${ }^{7}$ 


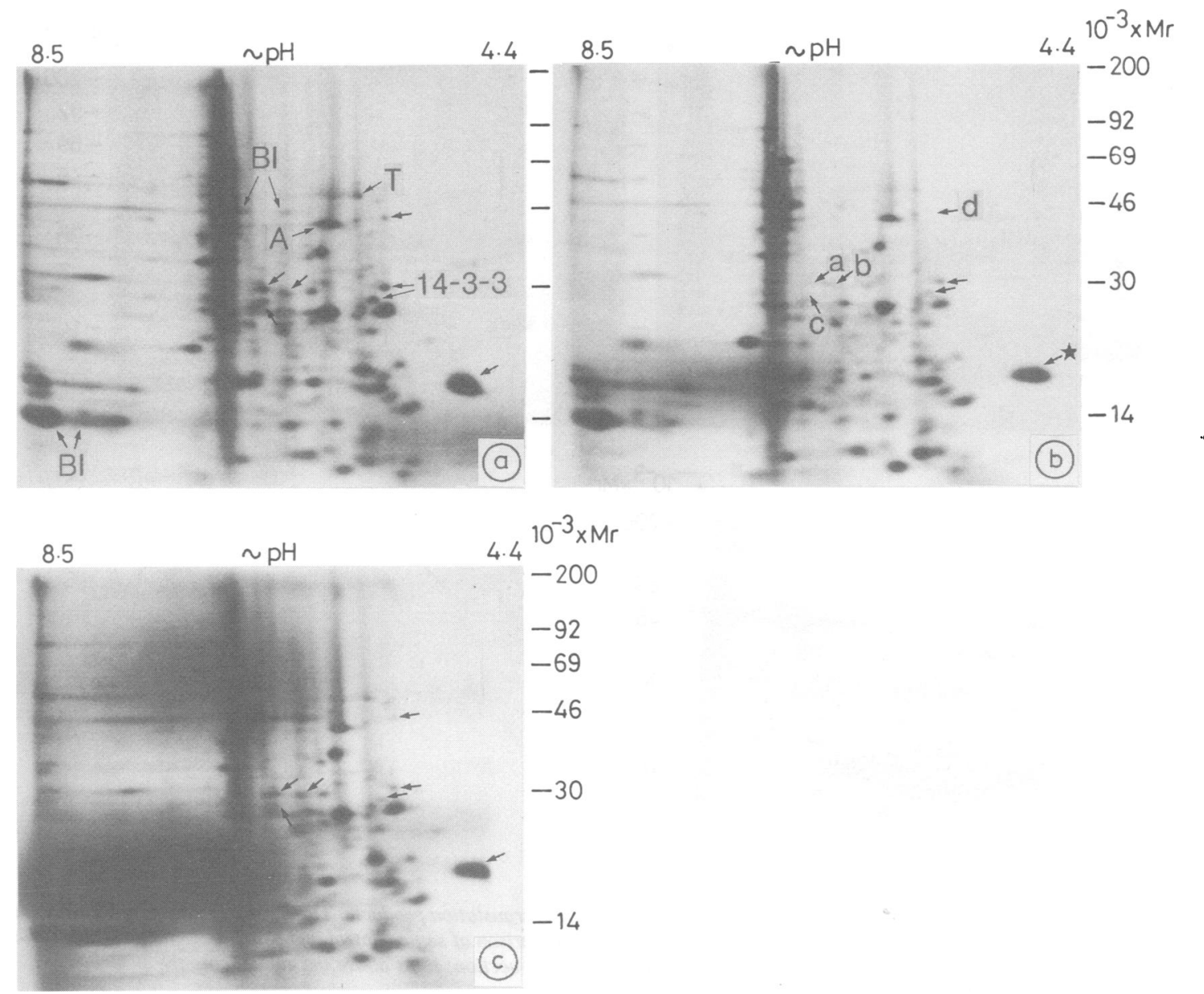

Fig 4 Two-dimensional ISODALT polyacrylamide-gel analysis of translation products. In vitro translation and gel analysis were performed as described in the Methods section. The sample contained $6 \times 10^{4}$ acid-precipitable c.p.m. Key:

(a), translation products of poly $(A)$-containing messenger $R N A$ isolated from control subjects; (b) translation products of poly $(A)$-containing messenger RNA isolated from schizophrenics; (c) translation products of poly $(A)$-containing messenger $R N A$ isolated from depressives; $a, b, c, d$, spots whose fluorographic intensities changed in a comparison of some control and psychiatric subjects; ( ), the standard spot for the ISODALT system, as described in the Methods section; right-hand scale represents the migration of $\mathrm{Mr}$ markers run on the same gel; numbers above the gel indicate the pH of the ends of the isoelectric-focusing gels. Abbreviations: A, actin; $T$, tubulin; 14-3-3, brain 14-3-3 protein; $B 1,\left[{ }^{35} S\right]$ methionine-binding proteins of the lysate system.

may reflect the developmental period studied (adult brain compared with foetal brain), since similar size distributions have been observed by other authors in adult post-mortem brain. ${ }^{2022}$ In addition, no consistent selective loss of individual species was observed with increased post-mortem delay.

The observation that intact messenger RNA, capable of translating proteins in the in vitro system, was obtained at post-mortem delays of up to 84 hours is significant, since such translation is highly dependent on the integrity of the $5^{1}$-terminal cap structure in brain messenger RNA. ${ }^{23}$ This extends the results of other studies indicating that messenger RNA seems intact for periods of up to 36 hours post-mortem ${ }^{1521}$ and confirms that the use of messenger RNA samples, extracted post-mortem from human brain, is likely to 


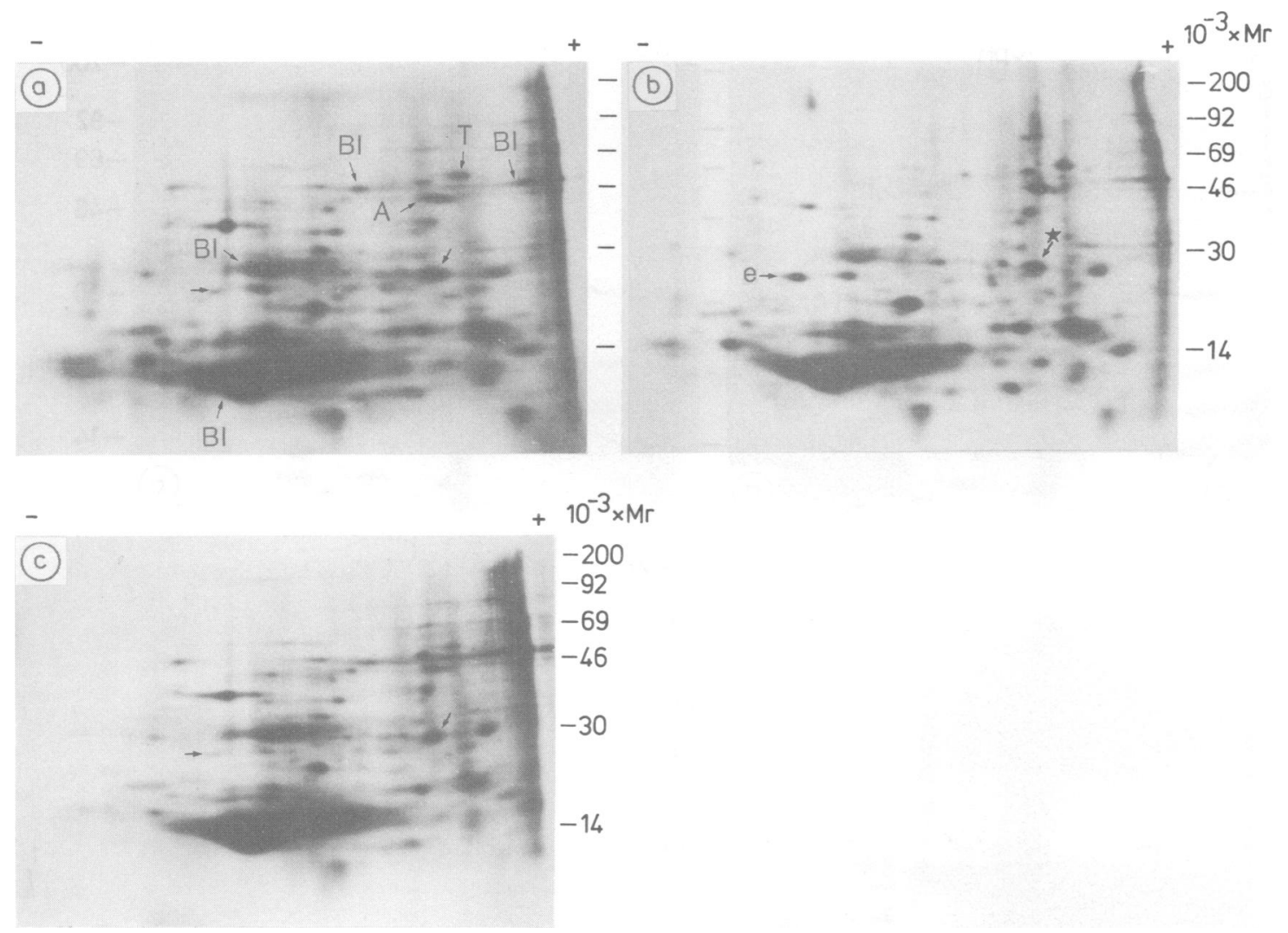

Fig 5 Two-dimensional BASODALT polyacrylamide-gel analysis of translation products. The legend is generally the same as in fig 4. Key: $e$, a spot whose fluorographic intensity changed in a comparison of some control and psychiatric subjects; ( $\star$ ), the standard spot for the BASODALT system, as described in the Methods section; signs above the gel indicate the electrode polarity for the BASODALT separation.

Table 4 Comparison of specific spot intensities on fluorograms shown in figs 4 and 5

\begin{tabular}{lcc}
\hline Spot & $\begin{array}{l}\text { Schizophrenics } \\
(\%) \dagger\end{array}$ & $\begin{array}{l}\text { Depressives } \\
(\%) \dagger\end{array}$ \\
\hline a & 4 & 93 \\
b & 5 & 100 \\
c & 0 & 96 \\
d & 0 & 100 \\
e & 3333 & 89 \\
14-3-3 & 35 & 35 \\
(basic) & $35-3$ & 26 \\
(acidic) & 26 & \\
\hline
\end{tabular}

*Spot designations as in figs 4 and 5 .

†Intensities were measured and normalised against the standard spots shown in figs 4 and 5 . Values are expressed as a percentage of control intensities. provide information on expressed genes in neuropsychiatric conditions. Indeed, the data presented in this study suggest that the state of the tissue premortem may be more important than post-mortem delays in tissue sampling in determining both recovery and biological activity of RNA species. It is possible, however, that important changes occur within 33 hours postmortem; we are therefore currently studying samples of this time interval.

With these considerations in mind, in this study we found no consistent significant differences on fluorograms between the control and psychiatric groups which suggests that, at least in the samples studied here, changes in abundant messenger RNA populations are not a feature of the disease state. Fur- 
ther analysis of the rarer populations using cDNA cloning techniques is now under way to obtain a more complete picture of these processes.

The support of the Medical Research Council (Grant No. G8514318N) is gratefully acknowledged.

\section{References}

1 Dunner DL. Recent genetic studies of bipolar and unipolar depression. In: Davis JM, Maas JW, eds. The Affective Disorders. Washington: American Psychiatric Press, 1983:183-91.

2 Murray RM, Lewis SW, Reveley AM. Towards an aetiological classification of schizophrenia. Lancet 1985;i:1023-6.

3 Egeland JA, Gerhard DS, Pauls DL, et al. Bipolar affective disorders linked to DNA markers on chromosome 11. Nature 1987:325:783-7.

4 Baron M, Risch N, Hamburger R, et al. Genetic linkage between $\mathrm{X}$-chromosome markers and bipolar affective illness. Nature 1987;326:289-92.

5 Hodgkinson S, Sherrington R, Gurling H, et al. Molecular genetic evidence for heterogeneity in manic depression. Nature 1987;325:805-6.

6 Perrett CW, Whatley SA. An analysis of the products of translation in vitro from normal and schizophrenic brain by twodimensional polyacrylamide-gel electrophoresis. Biochem Soc Trans 1987;15:546-7.

7 Whatley SA, Hall C, Davison AN, Lim L. Alterations in the relative amounts of specific mRNA species in the developing human brain in Down's Syndrome. Biochem J 1984;220: 179-87.

8 Hall C, Lim L. Developmental changes in the composition of polyadenylated RNA isolated from free and membrane-bound polyribosomes of the rat forebrain, analysed by translation in vitro. Biochem J 1981;196:327-36.

9 O'Farrell PH. High resolution two-dimensional electrophoresis of proteins. J Biol Chem 1975;250:4007-21.

10 O'Farrell PZ, Goodman HM, O'Farrell PH. High resolution twodimensional electrophoresis of basic as well as acidic proteins. Cell 1977;12:1133-42.
11 Quitschke W, Schechter N. A noncomputerized scanning method for determining relative quantities and synthesis rates on twodimensional electrophoretic gels. Analyt Biochem 1982;124: 231-8.

12 Arrand JE. Preparation of nucleic acid probes. In: Hames BD, Higgins SJ, eds. Nucleic Acid Hybridisation: A Practical Approach. Oxford: IRL Press, 1985:17-45.

13 Sajdel-Sulkowska EM, Marotta CA. Alzheimer's disease brain: Alterations in RNA levels and in a ribonuclease-inhibitor complex. Science 1984;225:947-9.

14 Guillemette JG, Wong L, Crapper McLachlan DR, Lewis PN. Characterization of messenger RNA from the cerebral cortex of control and Alzheimer-afflicted brain. $J$ Neurochem 1986;47:987-97.

15 Johnson SA, Morgan DG, Finch CE. Extensive post-mortem stability of RNA from rat and human brain. $J$ Neurosci Res 1986;16:267-80.

16 Wood TL, Frantz GD, Menkes JH, Tobin AJ. Regional distribution of messenger RNAs in post-mortem human brain. J Neurosci Res 1986;16:311-24.

17 Naber D, Dahnke HG. Protein and nucleic acid content in the aging human brain. Neuropathol Appl Neurobiol 1979;5:17-24.

18 Perry EK, Perry RH, Tomlinson BE. The influence of agonal status on some neurochemical activities of post mortem human brain tissue. Neurosci Lett 1982;29:303-8.

19 Gilbert JM, Brown BA, Strocchi P, Bird ED, Marotta CA. The preparation of biologically active messenger RNA from human postmortem brain tissue. J Neurochem 1981;36:976-84.

20 Marotta CA, Brown BA, Strocchi P, Bird ED, Gilbert JM. In vitro synthesis of human brain proteins including tubulin and actin by purified post mortem polysomes. J Neurochem 1981;36:966-75.

21 Morrison MR, Griffin WST. The isolation and in vitro translation of undegraded messenger RNAs from human post mortem brain. Analyt Biochem 1981;113:318-24.

22 Sajdel-Sulkowska E, Coughlin JF, Marotta CA. In vitro synthesis of polypeptides of moderately large size by poly(A)-containing messenger RNA from post mortem human brain and mouse brain. J Neurochem 1983;40:670-80.

23 Murthy MRV. Effects of cap analogue or cap removal on the translation of rat brain mRNA in vitro. $J$ Neurochem 1982;38:41-51. 